\title{
Avian Sex Determination Based on Chromo Helicase DNA-binding (CHD) Genes Using Polymerase Chain Reaction (PCR)
}

\author{
I. Khaerunnisa*, E. Sari, M. Ulfah, Jakaria, \& C. Sumantri \\ Department of Animal Production and Technology, Faculty of Animal Science, \\ Bogor Agricultural University \\ Jln. Agatis, Kampus IPB Dramaga, Bogor, 16680, Indonesia \\ (Received 09-01-2013; Reviewed 18-02-2013; Accepted 09-07-2013)
}

\begin{abstract}
Several bird species are sexually monomorphic. In this case, molecular approach is an efficient method for their sex determination. The sexes of monomorphic birds can be determined by PCR amplification of the CHD genes. CHD genes are preserved within avian $\mathrm{Z}$ and $\mathrm{W}$ sex chromosomes. The objective of this research was to determine sex of 21 individuals quails, pigeons, hill myna, salmon-crested cockatoos, and yellow-crested cockatoos based on CHD genes using two pairs of primers: 2550F-2718R and P2-P8. Samples from Kampong chickens and ducks were used as controls. PCR products were screened by agarose gel electrophoresis with ethidium bromide. Results showed that $2550 \mathrm{~F}$ and $2718 \mathrm{R}$ primers could be used to identify sex of Kampong chickens, quails, ducks, pigeons, hill myna, salmon-crested cockatoos, and yellow-crested cockatoos. Individuals showed double (ZW) and single (ZZ) bands were identified as females and males, respectively in Kampong chickens, quails, hill myna, salmon-crested cockatoos and yellow-crested cockatoos. Males and females in ducks and pigeons showed single band in different length of base pairs. P2 and P8 primers could be used to identify the sex of pigeons, hill myna, salmon-crested cockatoos, and yellow-crested cockatoos. All of those samples showed bouble (ZW) bands for females and single (ZZ) band for males.
\end{abstract}

Key words: avian, CHD genes, PCR, sex determination

\section{ABSTRAK}

Beberapa jenis burung memiliki jenis kelamin yang sulit dibedakan. Pada kasus tersebut, pendekatan molekular merupakan metode yang efisien untuk identifikasi jenis kelamin. Jenis kelamin burung monomorfik dapat ditentukan dengan amplifikasi gen CHD. Gen CHD terdapat di kromosom $Z$ maupun $W$. Tujuan penelitian ini adalah untuk menentukan jenis kelamin 21 ekor puyuh jepang, merpati, beo nias, kakatua maluku, dan kakatua-kecil jambul-kuning berdasarkan gen CHD menggunakan dua pasang primer: 2550F-2718R dan P2-P8. Sampel ayam kampung dan itik yang telah diketahui jenis kelaminnya digunakan sebagai kontrol. Produk PCR divisualisasikan melalui agarose gel electrophoresis dengan ethidium bromida. Hasil menunjukkan bahwa primer 2550F dan 2718R dapat digunakan untuk mengidentifikasi jenis kelamin ayam kampung, puyuh jepang, itik, merpati, beo nias, kakatua maluku, dan kakatua-kecil jambul-kuning. Masing-masing menunjukkan dua pita dan satu pita berturut-turut pada sampel betina dan jantan ayam kampung, puyuh jepang, beo nias, kakatua maluku, dan kakatua-kecil jambul-kuning. Jantan dan betina pada itik dan merpati menunjukkan satu pita dengan panjang basa yang berbeda. Primer P2-P8 dapat digunakan untuk mengidentifikasi jenis kelamin merpati, beo nias, kakatua maluku, dan kakatuakecil jambul-kuning. Saluruh sampel menunjukkan pita ganda ( $Z$ dan $W$ ) untuk betina dan pita tunggal (Z) untuk sampel jantan.

Kata kunci: aves, gen CHD, PCR, penentuan jenis kelamin

*Corresponding author:

E-mail: isyanakhaerunnisa@gmail.com 


\section{INTRODUCTION}

Sex determination is an important activity in avian breeding. However, sex identification of young and many adult birds is difficult because several birds have similar phenotipic traits both males and females (sexually monomorphism), even after puberty (Vali \& Doosti, 2011). That due to most breeders have doubt to identify the sex of birds they breed.

Sex determination can be identified using some basic methods: (1) behavioural observation, (2) presence of brooding patch, (3) differences in morphometric traits, (4) examination of the gonads by laparotomy or laparoscopy, and (5) examination of sex chromosomes. Generally, first and second method can be used only on breeding seasons, sex identification based on morphometric traits is difficult to practice. Examination of gonads is difficult outside breeding seasons (when the gonads regress) and because of their small body size compared with another animals (Dubiec \& ZagalskaNeubauer, 2006; Kocijan et al., 2011). Cardoni et al. (2009) sexed grassland birds using discriminant function analysis (DFA) on morphological measurements. The result showed that the discriminant function correctly determined the sex of only $80 \%$ of the overall samples.

Karyotyping also used for sex identification with comparing the size of male and female sex chromosomes (Archawaranon, 2004). However, this method needs 14$15 \mathrm{~d}$ for pinfeathers growing and ready to be analized. Cerit \& Avanus (2007a) reported that vent sexing, laparoscopy steroid sexing and karyotyping methods were unreliable, time-consuming, and expensive while some of them could be painful and even life-threatening for birds. Nestling, in particular, pose greater difficulties in determining their sex based in their morphological traits because their external characters and other signs are not fully developed yet (Lee et al., 2008). Lalev et al. (2012) and Mincheva et al. (2012) showed that chickens could be sexed using autosexing by feather colour and slowfeathering or rapid-feathering.

Sex determination using molecular approach is more accurate than other methods. This method can be applied also for juveniles. The most universal tag for sex determination is provided by the Chromo Helicase DNA-binding (CHD) genes. CHD genes itself have important role in chromatin remodeling in the control of transcription elongation (Simic et al., 2003). CHD contains at least two introns which differ in length in the $\mathrm{Z}$ and $\mathrm{W}$ chromosomes. This allows discrimination between the products from the $\mathrm{Z}$ and $\mathrm{W}$ chromosomes on a gel (Dubiec \& Zagalska-Neubauer, 2006).

CHD genes identified by 2550F-2718R primers designed by Fridolfsson \& Ellegren (1999) and P2-P8 primers designed by Griffits et al. (1998) using Polymerase Chain Reaction (PCR) technique. This technique uses to copy the target sequence between the primers (Williams, 2005). Those two pairs of primers are commonly used for avian sexing (Dubiec \& Zagalska-Neubauer, 2006; Kocijan et al., 2011; Sulandari \& Zein, 2012).

In avian, DNA is commonly obtained from blood. A small amount of blood is collected by puncture of the wing or leg vein (Dubiec \& Zagalska-Neubauer, 2006). Another method, DNA can be isolated from avian feathers. Feather sample collection gives less pain to the bird than blood sample collection. Additionally, its lower cost, less risk of DNA contamination and breakage, make this method preferable (Cerit \& Avanus, 2007b).

Similar studies have done in some countries, such as sex determination of Nymphicus hollandicus (Psittacidae) in Turkey (Cerit \& Avanus, 2007b), Japanese quail in Europe (Morinha et al., 2011), auklets in North Pacific and Bearing Sea (Dawson et al., 2001), and East Asian bird species (Lee et al., 2008). However, in Indonesia information about avian sex determination based on molecular approach does not exist yet, especially for endemic species. Hence, breeders in Indonesia have to send their bird's blood or feather samples to other countries for sex identification. The objective of this study was to determine sex of Japanese quails, pigeons, hill myna, salmon-crested cockatoos, and yellow-crested cockatoos, based on CHD genes using 2550-2718R and P2-P8 primers.

\section{MATERIALS AND METHODS}

\section{Samples}

Seven species of avian were identified which sex of Kampong chickens and ducks have been morphologically identified (Table 1). Those 2 species were used as controls. DNA samples were taken from avian blood and feather.

\section{DNA Extraction}

Blood samples. DNA extraction from blood sample was

Table 1. Avian samples used in study

\begin{tabular}{|c|c|c|c|c|}
\hline Scientific name & Common name & Family & Morphologically sexed & Number of sample \\
\hline Gallus gallus domesticus & Kampong chicken & Phasianidae & Yes & 4 \\
\hline Coturnix c. japonica & Japanese quail & Phasianidae & No & 4 \\
\hline Anas platyrhynchos & Duck & Anatidae & Yes & 4 \\
\hline Columba livia & Pigeon & Columbidae & No & 4 \\
\hline Gracula religiosa robusta & Hill myna & Sturnidae & No & 1 \\
\hline Cacatua moluccensis & Salmon-crested cockatoo & Psittacidae & No & 2 \\
\hline Cacatua sulphurea & Yellow-crested cockatoo & Psittacidae & No & 2 \\
\hline
\end{tabular}


modified from Sambrook \& Russell (2001). Each $50 \mu \mathrm{L}$ of blood samples from Kampong chickens, ducks, Japanese quails, and pigeons was added with $800 \mu \mathrm{L}$ RBC lysis buffer, homogenized, and sentrifuged (800 rpm) for $5 \mathrm{~min}$. Then, supernathan part was removed. The precipitation part was added by $40 \mu \mathrm{L}$ SDS 10\%, $10 \mu \mathrm{L}$ Proteinase K $5 \mathrm{mg} / \mathrm{mL}$, and $300 \mu \mathrm{L} 1 \times$ STE, and slowly shaked on $55^{\circ} \mathrm{C}$ incubator for $2 \mathrm{~h}$. Then, each sample was added by $400 \mu \mathrm{L}$ phenol solution, $400 \mu \mathrm{L}$ CIAA, and 40 $\mu \mathrm{L} \mathrm{NaCl} 5 \mathrm{M}$, slowly shaked on room temperature for an hour, and sentrifuged (12000 rpm) for $5 \mathrm{~min}$. About 400 $\mu \mathrm{L}$ liquid from top layer was moved into new tube and added with $800 \mu \mathrm{l}$ absolute $\mathrm{EtOH}$ and $40 \mu \mathrm{L} \mathrm{NaCl} 5 \mathrm{M}$. Then, samples were freezed overnight. DNA molecule was sentrifuged (12000 rpm) for $5 \mathrm{~min}$, and supernathan part was removed. DNA precipitation was dried, and 100 $\mu \mathrm{L}$ TE $80 \%$ was added into the tube. DNA samples were freezed, and ready to be used.

Feather samples. DNA extraction from feather was used DNA extraction kit. Calamus from each feather was cut until became pieces. Calamus was added with $1000 \mu \mathrm{L}$ Yang with urea and $100 \mu \mathrm{L}$ proteinase $\mathrm{K} 10 \mathrm{mg} / \mathrm{mL}$, and incubated on $38{ }^{\circ} \mathrm{C}$ overnight. Then, each sample was added by $20 \mu \mathrm{L}$ proteinase $\mathrm{K} 10 \mathrm{mg} / \mathrm{mL}$, incubated on $55{ }^{\circ} \mathrm{C}$ for $2 \mathrm{~h}$, and sentrifuged (2000 rpm) for $5 \mathrm{~min}$. Each sample was added by $2500 \mu \mathrm{L}$ PB buffer, and $750 \mu \mathrm{L}$ from the sample mixture was moved into spin tube and sentrifuged $(13000 \mathrm{rpm})$ for $1 \mathrm{~min}$. This stage was repeated until the mixture was empty. Spin tube was moved onto new tube and added with $100 \mu \mathrm{L}$ elution buffer, then sentrifuged (13000 rpm) for $1 \mathrm{~min}$. DNA samples were stored on new tube and ready to be analized or stored in freezer.

DNA quality test. DNA quality isolated from blood and feather were measured by 260 and $280 \mathrm{~nm}$ wavelengths in spectrophotometer (quantitatively) and 1.5\% agarose gel electroporesis (qualitatively).

\section{DNA Amplification and Electrophoresis}

CHD genes were amplified using polymerase chain reaction (PCR) technique with thermocycler machine. Amplification was performed in $23 \mu \mathrm{L}$ total volume: 1-2 $\mu \mathrm{L}$ DNA sample, 18.8-18.9 $\mu \mathrm{L}$ destilated water, 0.3 $\mu \mathrm{L}$ dNTPs; $1 \mu \mathrm{L} \mathrm{MgCl}$; $2.5 \mu \mathrm{L}$ dream taq buffer; $0.1 \mu \mathrm{L}$ taq Polymerase enzime; and $0.3 \mu \mathrm{L}$ primer. Two pairs of primer used this study were showed in Table 2.

First stage of amplification was an initial denaturation step at $95^{\circ} \mathrm{C}$ for $5 \mathrm{~min}$, then was followed by 35 cycles of denaturation step at $95^{\circ} \mathrm{C}$ for $30 \mathrm{~s}$, annealing

Table 2. Primer sequences used in study

\begin{tabular}{ccll}
\hline Primer & Code & \multicolumn{1}{c}{ Sequence $\left(5^{\prime}-3^{\prime}\right)$} & \multicolumn{1}{c}{ Reference } \\
\hline Forward & 2550F & GTTACTGATTCGTCTACGAGA & $\begin{array}{l}\text { Fridolfsson } \\
\text { \& Ellegren } \\
(1999)\end{array}$ \\
Reverse & 2718R & ATTGAAATGATCCATGCTTG & $\begin{array}{l}\text { Griffiths et } \\
\text { al. }(1998)\end{array}$ \\
Forward & P8 & CTCCCAAGGATGAGRAAYTG \\
Reverse & P2 & TCTGCATCGCTAAATCCTTT & \\
\hline
\end{tabular}

at $55-60{ }^{\circ} \mathrm{C}$ for $45 \mathrm{~s}$, and extention at $72{ }^{\circ} \mathrm{C}$ for $1 \mathrm{~min}$. Final extention stage at $72{ }^{\circ} \mathrm{C}$ for 5 min was needed to complete program. PCR products were visualized on agarose gel electrophoresis with ethidium bromide. Agarose concentration for PCR products of 2550F-2718R and P2-P8 primers were $1.5 \%$ and $2 \%$, respectively.

\section{Results Interpretation}

Sex of individuals were identified by single band or double bands showed above UV transilluminator. Single band was identified as male, and double bands were identified as female (Cerit \& Avanus, 2007b; Dawson et al., 2001; Griffith et al., 1998).

\section{RESULTS AND DISCUSSION}

\section{DNA Quality}

DNA purity from both blood and feather were low (Table 3). Marerro et al. (2009) reported that DNA molecule classified as pure if ratio $\mathrm{A}_{260}$ and $\mathrm{A}_{280}$ more than 1.8. That was caused by DNA contaminants such as blood proteins in blood and keratin in feathers. Tataurov et al. (2008) reported that nucleid acid could be contaminated by the other molecules such as protein, organic compounds, etc. Pough et al. (2005) also explained that more than $90 \%$ component of feather is beta keratin, $8 \%$ water, $1 \%$ lipid, and $1 \%$ protein and pigmen. Keratin could be the contaminant and also inhibitor for PCR (Schill, 2007). The inhibitor factor in feather caused some difficulties to extract the DNA, therefore those could be extracted using kit extraction. Schill (2007) also explained that DNA extraction using kits resulted better quality of DNA.

DNA concentration from blood was higher than feather (Table 3). Blood contains more nuclears than feather. Nuclears from feather are available in epitel cells in calamus. Calamus is a part of feather which remains firmly implant in skin (Pough et al., 2005).

Test of DNA quality using 1.5\% agarose gel was determined by light intensity of DNA bands on gel. DNA bands from blood were lighter than DNA bands from feather (Figure 1). This due to DNA concentration from blood was higher than feather.

The most common method of acquiring genetic material for molecular sexing is blood sampling (Harvey et al., 2006). However, some species of avian have very smooth blood vessels, such as in cockatoos (Psittacidae) and hill mynas (Sturnidae). Blood collection was very difficult to apply and might cause stress. Application of DNA from feathers could decrease the stress and easy sample collection for small body of avian (Bello et al., 2001). Taking feather samples from a bird is less

Table 3. Average of DNA purity and concentration

\begin{tabular}{lccc}
\hline $\begin{array}{l}\text { Source of } \\
\text { DNA }\end{array}$ & $\mathrm{n}$ & $\begin{array}{c}\text { Purity } \\
\left(\mathrm{A}_{260} / \mathrm{A}_{280}\right)\end{array}$ & $\begin{array}{c}\text { Concentration } \\
(\mu \mathrm{g} / \mathrm{mL})\end{array}$ \\
\hline Blood & 16 & 1.410 & 795 \\
Feather & 5 & 1.399 & 224 \\
\hline
\end{tabular}




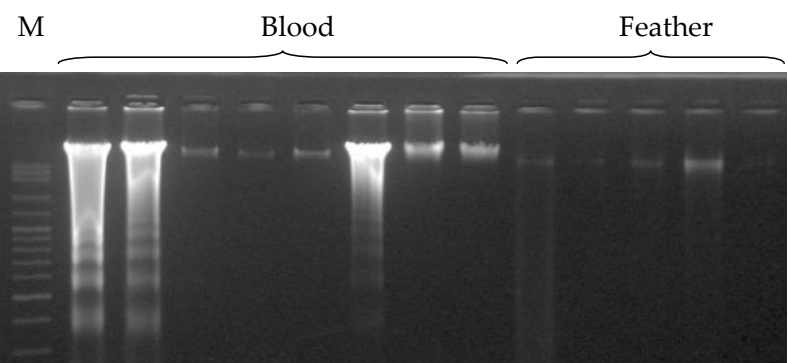

Figure 1. Electrophoresis extracted DNA using 1.5\% agarose gel

time consuming, simpler, avoid pain, less stressful, and reduce contamination risk than blood sampling (Cerit \& Avanus, 2007b; Kocijan et al., 2011).

\section{Amplification of Chromo Helicase DNA-binding (CHD) Genes}

A total of 21 individuals of avian were successfully sexed by $2550 \mathrm{~F}-2718 \mathrm{R}$ primers using $60{ }^{\circ} \mathrm{C}$ annealing temperature for Kampong chickens and Japanese quails, and $55{ }^{\circ} \mathrm{C}$ annealing temperature for ducks, pigeons, hill myna, salmon-crested cockatoos, and yellow-crested cockatoos (Figure 2).

All of male individuals were showed by single band and females were showed by double bands except in ducks and pigeons. Single band in males avian was identified as CHD-Z gene (located in Z chromosome). However, double bands in females were identified as CHD-Z gene and CHD-W (located in W chromosome). Birds have female heterogamet with $\mathrm{Z}$ and $\mathrm{W}$ sex chromosomes (Nam \& Ellegren, 2008). Consequently, males were identified by single band and females by double bands on gel, with some exception (Cerit \& Avanus, 2007b; Dubiec \& Zagalska-Neubauer, 2006). Dubiec \& Zagalska-Neubauer (2006) explained that the 2550F2718R primers may produce only 1 fragment both in males and females of some species. However, females in ducks and pigeons were differentiated from males based on the difference of their fragment length using 2550F2718R primers.

Kampong chickens, Japanese quails, and ducks were not successfully sexed using P2-P8 primers (Table

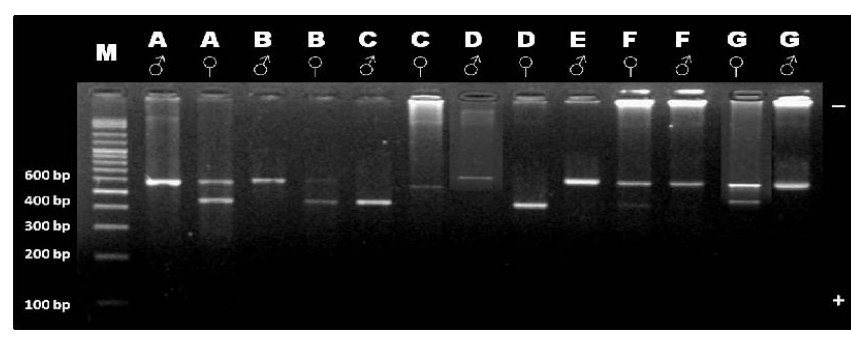

Figure 2. Sex typing using 2550F-2718R primers with $1.5 \%$ agarose gel electrophoresis in seven species of avian: (A) Kampong chicken, (B) Japanese quail, (C) duck, (D) pigeon, (E) hill myna, (F) salmon-crested cockatoo, $(\mathrm{G})$ Yellow-crested cockatoo, and (M) marker.
4). The P2-P8 primers produce only 1 fragment in both sexes using agarose gel. To increase the power of resolution in the separation of amplified fragments, Morinha et al. (2011) used PCR-SSCP technique. However, pigeons, hill myna, salmon-crested cockatoos, and yellow-crested cockatoos showed single band and double bands, respectively in males and females. Amplification of CHD genes using P2-P8 primers were showed in Figure 3.

Fragment length of CHD genes in several species of avian amplified by 2550F-2718R and P2-P8 primers were showed in Table 5. In general, the differences in size between $\mathrm{Z}$ and $\mathrm{W}$ specific fragments amplified with the 2550F-2718R primers ranges from 150 to $250 \mathrm{bp}$, while for the P2-P8 primers, from 10 to $80 \mathrm{bp}$ (Fridolfsson \& Ellegren, 1999; Jensen et al., 2003). The lack of CHD-Z and CHD-W in Japanese quail is 6. Therefore, this species was not successfully sexed using P2-P8 primers.

Table 4. List of molecularly sexed species included in the study with 2550F/2718R and P2/P8 primers

\begin{tabular}{lccc}
\hline Species & $\begin{array}{c}\text { Sample } \\
\text { type }\end{array}$ & $\begin{array}{c}2550 \mathrm{~F} / \\
2718 \mathrm{R}\end{array}$ & P2/P8 \\
\hline Gallus gallus domesticus & Blood & Yes & No \\
Coturnix c. japonica & Blood & Yes & No \\
Anas platyrhynchos & Blood & Yes & No \\
Columba livia & Blood & Yes & Yes \\
Gracula religiosa robusta & Feather & Yes & Yes \\
Cacatua moluccensis & Feather & Yes & Yes \\
Cacatua sulphurea & Feather & Yes & Yes \\
\hline
\end{tabular}

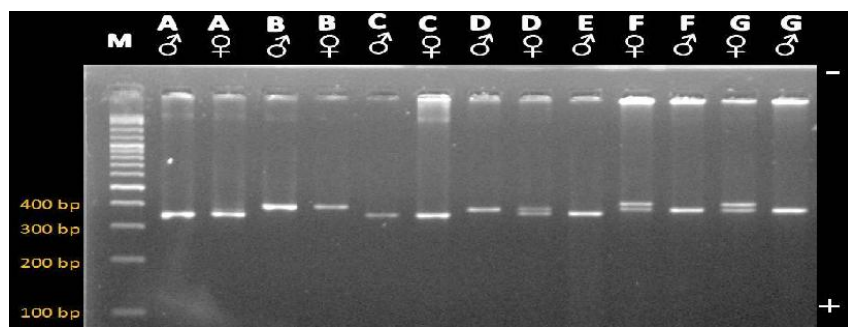

Figure 3. Sex typing using P2-P8 primers with 2\% agarose gel electrophoresis in seven species of avian: (A) Kampong chicken, (B) Japanese quail, (C) duck, (D) pigeon, (E) hill myna, (F) salmon-crested cockatoo, $(\mathrm{G})$ yellowcrested cockatoo, and $(\mathrm{M})$ marker.

\section{Implementation of Avian Sex Determination in Indonesia}

Sex determination using molecular approach may be used as a basic or a complement for breeding program, and conservation program of endangered species of bird such as cockatoos and mynas. Most bird species are traded for pets, while a few species are traded for food, and to a far lesser extent, for medicinal and folk magic purposes (Shepherd, 2006). Soehartono \& Mardiastuti (2002) reported that hill myna, salmon-crest- 
Table 5. Fragment length of Chromo Helicase DNA-binding (CHD) genes in several species of avian

\begin{tabular}{|c|c|c|c|c|c|}
\hline Primer & Species & Gene & $\begin{array}{l}\text { Fragment } \\
\text { length (bp) }\end{array}$ & $\begin{array}{l}\text { Lack of CHD-Z and } \\
\text { CHD-W (bp) }\end{array}$ & $\begin{array}{c}\text { GenBank access number } \\
\text { (http://www.ncbi.nlm.nih.gov/) }\end{array}$ \\
\hline \multirow[t]{4}{*}{ 2550F-2718R } & \multirow[t]{2}{*}{ Columba livia } & CHD-Z & 656 & \multirow{2}{*}{208} & AY517719 \\
\hline & & CHD-W & 448 & & AY517718 \\
\hline & \multirow[t]{2}{*}{ Gallus gallus } & CHD-Z & 595 & \multirow{2}{*}{148} & GU132943 \\
\hline & & CHD-W & 447 & & GU132944 \\
\hline \multirow[t]{4}{*}{ P2-P8 } & \multirow[t]{2}{*}{ Columba livia } & CHD-Z & 370 & \multirow{2}{*}{20} & GU289183 \\
\hline & & CHD-W & 350 & & GU289184 \\
\hline & \multirow{2}{*}{$\begin{array}{l}\text { Coturnix c. } \\
\text { japonica }\end{array}$} & CHD-Z & 385 & \multirow[b]{2}{*}{6} & HQ175997 \\
\hline & & CHD-W & 379 & & HQ175998 \\
\hline
\end{tabular}

ed cockatoo, and yellow-crested cockatoo were listed in Appendix CITES. In Nias island, Hill mynas catch and sell, although legally protected and rare species, as well as species valued as song birds, are often preferred, as they command higher prices. Since 2002, Indonesia has not permitted to export of any Appendix 1 and 2 CITES-listed birds species, except for captive breeding purposes or F1 of Appendix 2 CITES listed birds species (Shepherd, 2006). To fulfill the high demands of these birds, captive breeding may be the solution without caused population decreasing in nature. Accurately of avian sex determination may stimulate success of captive breeding program and hopefully, this may increase the population of Indonesian endemic birds.

\section{CONCLUSION}

The 2550F-2718R primers are successful to determine sex of Kampong chickens, ducks, Japanese quails, pigeons, hill myna, salmon-crested cockatoos, and yellow-crested cockatoos. However, the P2-P8 primers are successful to determine sex of pigeons, hill myna, salmon-crested cockatoos, and yellow-crested cockatoos.

\section{ACKNOWLEDGEMENT}

Authors thank to sample providers, those are Laboratory of Animal Molecular Genetics, Department of Animal Production and Technology, Faculty of Animal Science, Bogor Agricultural University; Dr. Ir. Sri Darwati, M.Si.; and Megananda Bird Orchid Farm, Ciluer, Bogor, West Java.

\section{REFERENCES}

Archawaranon, M. 2004. Rapid sexing Hill Mynah Gracula religiosa by sex chromosomes. Biotech. 3: 160-164. http:// dx.doi.org/10.3923/biotech.2004.160.164

Bello, N., O. Francino, \& A. Sanchez. 2001. Isolation of genomic DNA from feathers. J. Vet. Diagn. Invest. 13: 162-164. http://dx.doi.org/10.1177/104063870101300212

Cardoni, D. A., J. E. Maldonado, J. P. Isacch, \& R. Greenberg. 2009. Subtle sexual dimorphismn in the bay-capped wrenspinetail (Spartonoica malurodes: Furnariidae) uncovered through molecular sex determination. Ornith. Neotrop. 20: 347-355.

Cerit, H. \& K. Avanus. 2007a. Sex identification in avian species using DNA typing methods. World's Poult. Sci. J. 63: 91-99. http://dx.doi.org/10.1017/S0043933907001316

Cerit, H. \& K. Avanus. 2007b. Sex determination by CHDW and CHDZ genes of avian sex chromosomes in Nymphicus hollandicus. Turk. J. Vet. Anim. Sci. 31: 371-374.

Dawson, D. A., S. Darby, F. M. Hunter, A. P. Krupa, I. L. Jones, \& T. Burke. 2001. A critique of avian CHD-based molecular sexing protocols illustrated by a Z-chromosome polymorphism detected in auklets. Mol. Eco. Notes. 1: 201-204. http://dx.doi.org/10.1046/j.1471-8278.2001.00060.x

Dubiec, A. \& M. Zagalska-Neubauer. 2006. Molecular techniques for sex identification in birds. Biological Lett. 43: 3-12.

Fridolfsson, A. K. \& H. Ellegren. 1999. A simple and universal method for molecular sexing of non-ratite birds. J. Avi. Bio. 30: 116-121. http://dx.doi.org/10.2307/3677252

Griffiths, R., M. C. Double, K. Orr \& R. J. G. Dawson. 1998. A DNA test to sex most birds. Mol. Ecol. 7: 1071-1075. http:// dx.doi.org/10.1046/j.1365-294x.1998.00389.x

Harvey, M. G., D. N. Bonter, L. M. Stenzler, \& I. J. Lovette. 2006. A comparison of plucked feathers versus blood samples as DNAsourcesformolecularsexing.J.FieldOrnith.77:136-140. http://dx.doi.org/10.1111/j.1557-9263.2006.00033.x

Jensen, T., F. M. Pernasetti, \& B. Durrant. 2003. Conditions for rapid sex determination in 47 avian species by PCR genomic DNA from blood, shell-membrane blood vessels, and feathers. Zoo Biology 22:561-571. http://dx.doi.org/10.1002/zoo.10101

Kocijan, I., P. Dolenec, T. Sinko, D. D. Nenadic, G. Pavokovic, \& Z. Dolonec. 2011. Sex-typing bird species with little or no sexual dimorphism: an evaluation of molecular and morphological sexing. J. Biol. Res.-Thessalon. 15: 145-150.

Lalev, M., M. Oblakova, N. Mincheva, P. Hristakieva, \& I. Ivanova. 2012. Evaluation of productive traits of chicken lines from the national gene pool. Tarkia J. Sci. 10: 38-42.

Lee, M. Y., Y. J. Hong, S. K. Park, Y. J. Kim, T. Y. Choi, H. Lee, \& M. S. Min. 2008. Application of two complementary molecular sexing methods for East Asian bird species. Genes \& Genomics. 30: 365-372.

Marerro, P., R. Fregel, V. M. Cabrera, \& M. Nogales. 2009. Extraction of high-quality host DNA from feces and regurgitated seeds: a useful tool for vertebrate ecological studies. Biol. Res. 42: 147-151. http://dx.doi.org/10.4067/S071697602009000200002

Mincheva, N., M. Lalev, M. Oblakova, O. Hristakieva, \& I. Ivanova. 2012. Investigation on the frequency of alleles at the locus and their effect on the growth of two lines of Plymouth Rock chickens. Archiva Zootechnica 15: 69-75.

Morinha, F., M. Carvalho, A. Ferro, H. Guedes-Pinto, R. Rodrigues, \& E. Bastos. 2011. Molecular sexing and analysis of CHD1-Z and CHD1-W sequence variation in wild com- 
mon quail and domesticated Japanese quail. J. Genet. 90: 39-43.

Nam, K. \& H. Ellegren. 2008. The chicken (Gallus gallus) Z chromosome contains at least three nonliniear evolutionary strata. Genetics 180: 1131-1136. http://dx.doi.org/10.1534/ genetics.108.090324

Pough, F. H., C. M. Janis, \& J. B. Heiser. 2005. Vertebrate Life Seventh Edition. Pearson Prentice Hall, New Jersey.

Sambrook, J. \& D. Russell. 2001. Molecular Cloning: A Laboratory Manual, $3^{\text {rd }}$ ed. Cold Spring Harbor Laboratory Press, United States of America.

Schill, R. O. 2007. Comparison of different protocols for DNA preparation and PCR amplification of mitochondrial genes of tardigrades. J. Limnol. 66: 164-170. http://dx.doi. org/10.4081/jlimnol.2007.s1.164

Shepherd, C. R. 2006. The bird trade in Medan, North Sumatra: an overview. Birding ASIA 5: 16-24.

Simic, R., D. L. Lindstorm, H. G. Tran, K. L. Roinick, P. J. Costa, A. D. Johnson, G. A. Hartzog, \& K. M. Arndt. 2003. Chromatin remodeling protein CHD1 interacts with transcrip- tion elongation factors and localizes to transcribed genes. The Embo J. 22: 1846-1856. http://dx.doi.org/10.1093/emboj/cdg179

Soehartono, T. \& A. Mardiastuti. 2002. CITES Implementation in Indonesia. Nagao Natural Environment Foundation, Jakarta.

Sulandari, S. \& M. S. A. Zein. 2012. Application of two molecular sexing methods for Indonesian bird species: implication for captive breeding programs in Indonesia. HAYATI J. Biosci. 19: 183-190. http://dx.doi.org/10.4308/hjb.19.4.183

Tataurov, A. V., Y. You, \& R. Owczarzy. 2008. Predicting ultraviolet spectrum of single stranded and double stranded deoxyribonucleic acids. Biophys. Chem. 133: 66-70. http:// dx.doi.org/10.1016/j.bpc.2007.12.004

Vali, N. \& A. Doosti. 2011. Molecular study for sex identification in Japanese quails (Coturnix japonica). Afr. J. Biotechnol. 10: 18593-18596.

Williams, J. L. 2005. The use of marker-assisted selection in animal breeding and biotechnology. Rev. Sci. Tech. Off. Int. Epiz. 24: 379-391. 